\title{
Jumlah Kunjungan Wisatawan, Pajak Hotel, Pajak Restoran Dan Hiburan Terhadap Pendapatan Asli Daerah Kota Langsa
}

\author{
Iskandar*, Yani Rizal dan Muhammad Fadli Alkhanis \\ Fakultas Ekonomi, Universitas Samudra, Indonesia \\ *Corresponding author: iskandar@unsam.ac.id
}

\begin{abstract}
ABSTRAK
Penelitian ini bertujuan untuk mengetahui pengaruh jumlah kunjungan wisatawan, pajak hotel, pajak restoran dan hiburan terhadap pendapatan asli daerah Kota Langsa. Metode analisis data yang digunakan adalah persamaanregresi linier berganda, koefisien determinasi $\left(\mathrm{R}^{2}\right)$ serta uji $t$ dan $F$. Hasil uji persamaan regresi $\left(R^{2}\right)$ diperoleh $Y_{\log }=0,969+0,288 X_{1 \log }+0,579 X_{2 \log }+0,378 X_{3 \log }$, hasil ini menunjukkan bahwa jumlah wisatawan, pajak hotel, pajak restoran dan hiburan memberikan pengaruh positif terhadap pendapatan asli daerah di Kota Langsa. Hasil uji t jumlah wisatawan diperoleh bahwa jumlah wisatawan berpengaruh signifikan terhadap pendapatan asli daerah Kota Langsa. Pajak hotel diperoleh bahwa pajak hotel berpengaruh signifikan terhadap pendapatan asli daerah Kota Langsa. Pajak restoran dan hiburan diperoleh bahwa pajak restoran dan hiburan berpengaruh signifikan terhadap pendapatan asli daerah Kota Langsa. Dan hasil uji $\mathrm{F}$ dapat dinyatakan bahwa jumlah wisatawan, pajak hotel, pajak restoran dan hiburan berpengaruh signifikan terhadap pendapatan asli daerah Kota Langsa. Hasil uji koefisien determinasi $\left(\mathrm{R}^{2}\right)$ 0,952 atau sebesar 95,2\% variable jumlah wisatawan, pajak hotel, pajak restoran dan hiburan mempengaruhi pendapatan asli daerah Kota Langsa, dan sebesar 4,8\% dipengaruhi oleh variabel lain yang tidak masuk dalam estimasi penelitian
\end{abstract}

Kata Kunci: Wisatawan, Pajak Hotel, Pajak Restoran dan Hiburan, PAD

\begin{abstract}
This study aims to determine the effect of the number of tourist visits, hotel taxes, restaurant taxes and entertainment on the local revenue of Langsa City. The data analysis method used is multiple linear regression equation, coefficient of determination $(R 2)$ and $t$ and $F$ tests. The results of the regression equation test $(R 2)$ obtained Ylog $=0.969+0.288 X 1 \log +0.579 X 2 \log$ $+0.378 X 3 \mathrm{log}$, these results indicate that the number of tourists, taxes hotels, restaurant and entertainment taxes have a positive influence on local revenue in Langsa City. The results of the t-test of the number of tourists showed that the number of tourists had a significant effect on the local revenue of Langsa City. The hotel tax shows that the hotel tax has a significant effect on the local revenue of Langsa City. The restaurant and entertainment tax shows that the restaurant and entertainment tax has a significant effect on the local revenue of Langsa City. And the results of the F test can be stated that the number of tourists, hotel taxes, restaurant taxes and entertainment have a significant effect on the local revenue of Langsa City. The results of the coefficient of determination test (R2) 0.952 or $95.2 \%$ the variable number of tourists, hotel taxes, restaurant taxes and entertainment affects the local revenue of Langsa City, and $4.8 \%$ is influenced by other variables that are not included in the research estimate.
\end{abstract}

Keywords: Tourist, Hotel Tax, Restaurant and Entertainment Tax, PAD. 


\section{PENDAHULUAN}

Pembangunan nasional harus didukung oleh pemerintah dengan memberikan kesempatan dalam menyelenggarakan otonomi daerah berdasarkan Undang-Undang Nomor 32 Tahun 2004 tentang Pemerintahan Daerah dan Undang-Undang Nomor 33 Tahun 2004 tentang Perimbangan Keuangan antara Pemerintah Pusat dengan Pemerintah Daerah. Menurut Undang - Undang Nomor 32 Tahun 2004 tentang Pemerintahan Daerah, otonomi daerah adalah kewenangan daerah otonom untuk mengatur dan mengurus kepentingan masyarakat setempat menurut prakarsa sendiri berdasarkan aspirasi masyarakat sesuai dengan peraturan perundang-undangan. Kewenangan daerah mencakup kewenangan pemerintahan, mulai dari sistem perencanaan, pembiayaan maupun pelaksanaannya.

Pemberlakuan otonomi daerah atau desentralisasi fiskal yang merupakan pendelegasian kewenangan dan tanggung jawab fiskal dari pemerintah pusat kepada pemerintah daerah. Dengan diberlakukannya kebijakan desentralisasi fiskal, maka daerah diberikan kebebasan untuk mengatur sistem pembiayaan dan pembangunan daerahnya sesuai dengan potensi dan kapasitasnya masing-masing. Penyelenggaraan rumah tangganya sendiri, pemerintah daerah memerlukan dana yang tidak sedikit. Oleh karena itu, pemerintah daerah harus mengoptimalkan sumber-sumber penerimaan daerah dalam era otonomi daerah dan desentralisasi fiskal.

Pendapatan asli daerah menjadi indikator keberhasilan daerah dalam pembangunan, selain memberikan kesejahteraan kepada masyarakat juga memiliki pendapatan daerah. Untuk itu pendapatan suatu daerah perlu digali sehingga memperoleh pendapatan yang dapat mendanai setiap kegiatan pemerintah daerah. Pendapatan asli daerah dapat di peroleh suatu daerah melalui pajak daerah berupa pajak hotel, pajak restoran dan pajak hiburan. Menurut Undang Undang Nomor 34 tahun 2000, Undang-undang nomor 28 tahun 2009, dan Pasal 6 UU No. 33 Tahun 2004 ayat 1 dan 2 menyatakan bahwa, PAD bersumber dari Pajak Daerah, Retribusi Daerah, Hasil Pengelolaan Kekayaan Daerah yang Dipisahkan, Lain-lain Pendapatan Asli Daerah yang Sah.

Bila dikaitkan dengan pajak hotel, restoran dan hiburan maka salah satunya untuk mendapatkannya adalah melalui pariwisata. Pengertian PAD menurut Undang-undang No. 28 Tahun 2009 yaitu sumber keuangan daerah yang digali dari wilayah daerah yang bersangkutan yang terdiri dari hasil pajak daerah, retribusi daerah, hasil pengelolaan kekayaan daerah yang dipisahkn dan pendapatan lain-lain yang sah.

Pariwisata juga akan membantu mempercepat proses pertumbuhan ekonomi. Sebab pariwisata bisa dikatakan sebagai penggerak dari sektor-sektor lain seperti sektor industri dan jasa. Dampak positif pariwisata terhadap pembangunan ekonomi antara lain, dampak terhadap penciptaan lapangan kerja, sumber devisa negara dan distribusi pembangunan.

Adanya wisatawan yang datang ke suatu daerah dapat menambah pendapatan daerah melalui penginapan atau hotel, melalui makanan atau restoran dan juga apabila ada acara hiburan dapat memberikan pendapatan pajak hiburan. Jumlah wisatawan yang berkunjung ke suatu daerah sangat erat kaitannya terhadap pendapatan daerah itu sendiri.Semakin lama wisatawan tinggal di suatu daerah tujuan wisata, maka semakin banyak pula uang dibelanjakan di daerah tujuan wisata tersebut, paling sedikit untuk keperluan makan, minum, dan penginapan selama tinggal di daerah tersebut.

Hotel menjadi suatuperusahaan jasa atau badan usaha yang menyediakan layanan menginap untuk orang-orang yang melakukan perjalanan. Dikelola oleh pemilik atau ownernya dengan layanan tempat tidur beserta fasilitasnya makanan dan minuman serta fasilitas lengkap lainnya. Untuk dapat menggunakan layanan yang disediakan oleh pemilik hotel kepadakonsumennya, denganseseorang harus membayar tarif atau harga yang sudah ditentukanatauditetapkanolehpihak hotel. Hotel ini didirikan dengan bentuk bangunan yang 
dikelola oleh pemilik dengan tujuan komersial serta menyediakan fasilitas penginapan tersebut untuk masyarakat umum. Dengan rincian fasilitas seperti jasa penginapan, jasa pelayanan barang bawaan, jasa penyedia makanan dan minuman, jasa fasilitas perabot dan hiasan, serta jasa pencucian pakaian".

Selain ketersediaan obyek wisata yang menjadi tujuan wisata, ketersediaan akan sarana berupa hotel dan restoran merupakan hal yang wajib tersedia di daerah tujuan wisata. Kota Langsa, dengan segala daya tarik wisatanya dan fasilitas pendukung yang dimiliki, maka hotel dan restoran dapat dijadikan sebagai sumber pendapatan daerah melalui sektor pajak. Kondisi PAD Kota Langsa mengalami fluktuasi selama beberapa tahun terakhir. Untuk mendapatkan gambaran mengenai Pendapatan Asli Daerah (PAD) di Kota Langsa, dapat dilihat sebagai berikut:

Tabel 1. Pertumbuhan Pendapatan Asli Daerah Kota Langsa Tahun 2013-2019

\begin{tabular}{|c|c|c|c|}
\hline Tahun & Tarbel PAD $(\mathbf{R p})$ & Realiasai PAD $(\mathbf{R p )}$ & Persentasi $(\boldsymbol{\%})$ \\
\hline 2013 & $64.236 .271 .011,87$ & $57.243 .381 .959,77$ & 89,11 \\
\hline 2014 & $105.021 .202 .287,00$ & $114.168 .702 .058,30$ & 108,71 \\
\hline 2015 & $114.529 .994 .341,00$ & $109.116 .860 .676,13$ & 95,27 \\
\hline 2016 & $133.420175 .265,00$ & $121.369 .467 .375,72$ & 90,97 \\
\hline 2017 & $127.325 .504 .605,00$ & $120.138 .956 .032,87$ & 94.36 \\
\hline 2018 & $125.634 .683 .815,00$ & $121.316 .713 .328,93$ & 96,56 \\
\hline 2019 & $153.718 .784 .258,00$ & $115.244 .246 .710,49$ & 74,97 \\
\hline
\end{tabular}

Sumber: BPKD Kota Langsa, (2020).

Dari data tersebut diatas dapat diperoleh gambaran mengenai pertumbuhan PAD dalam tujuhtahun terakhir yaitu dari tahun 2013 sampai dengan tahun 2019. Pendapatan asli daerah mengalami penurunan pada tahun 2013. Pendapatan Asli Daerah Kota Langsa secara umum tahun 2013 sampai dengan 2015 mengalami pertumbuhan akan tetapi pada tahun 2015 realiasi mengalami penurunan. Pendapatan asli daerah Kota Langsa ini diperoleh dari berbagai sumber, seperti kunjungan wisatawan, pajak hotel, pajak restoran dan hiburan, dapat diketahui pada table 2 .

Diketahui jumlah kunjungan wisatawan di Kota Langsa mengalami fluktuasi. Demikian halnya pada penerimaan pajak hotel serta pajak restoran dan hiburan. Jumlah pengunjung wisatawan yang dating ke Kota Langsa sejak tahun 2013 sampai tahun 2019 mengalami fluktuasi. Terjadi peningkatan atau penurunan karena berbagai hal seperti pada tahun 2014, 2016, dan 2018 terjadi penurunan jumlah kunjungan wisatawan, sementara pajak hotel yang menjadi salah satu sumber pendapatan asli daerah. Hasil penelitian yang dilakukan oleh Widodo dan Guritno (2015), Widyaningsih dan Budhi (2014) dan Hutahean (2015) menunjukan bahwa ada pengaruh yang simultan dan signifikan antara Pajak Hotel, Pajak Restoran dan Pajak Hiburan terhadap Pendapatan Asli Daerah.

\section{KAJIAN PUSTAKA}

Berdasarkan Undang-Undang Nomor 33 Tahun 2004 tentang Perimbangan Keuangan antara Pemerintah Pusat dan Pemerintah Daerah, sumber penerimaan daerah terdiri dari Pendapatan Asli Daerah (PAD). Pengertian PAD menurut Undang-undang No. 28 Tahun 2009 yaitu sumber keuangan daerah yang digali dari wilayah daerah yang bersangkutan yang terdiri dari hasil pajak daerah, retribusi daerah, hasil pengelolaan kekayaan daerah yang dipisahkn dan pendapatan lain-lain yang sah. Pendapatan Asli Daerah (PAD) merupakan sumber penerimaan daerah yang berasal dari sumber-sumber dalam daerah sendiri, yang dipungut berdasarkan 
undang-undangan yang berlaku.Hal tersebut menuntut daerah untuk meningkatkan kemampuan dalam menggali dan mengelola sumber-sumber penerimaan daerah khususnya yang bersumber dari Pendapatan Asli Daerah (Pertiwi, 2014).

Nasrul (2003) menurut Sammeng wisatawan yaitu orang yang melakukan perjalanan atau kunjungan sementara secara sukarela ke suatu tempat di luar lingkungan tempat tinggalnya sehari-hari untuk maksud tertentu dan tidak memperoleh penghasilan tetap di tempat yang dikunjunginya".

Selanjutnya pengeluaran wisatawan tersebut menjadi sumber pendapatan bagi pemerintah daerah (PAD), pengusaha yang bergerak dibidang pariwisata dan masyarakat yang terlibat dalam kegiatan kepariwisataan (Nawawi, 2003). Kota Langsa yang strategis dan merupakan kota jasa dengan dukungan berbagai objek pariwisata. Hal ini menjadikan Kota Langsa sebagai daerah tujuan utama bagi para wisatawan untuk berkunjung ke Kota Langsa merupakan daerah pariwisata yang memiliki daya tarik tersendiri bagi wisatawan terutama wisatawan domestik.

Hotel adalah perusahaan atau badan usaha yang memberikan layanan penginapan berupa kamar yang biasanya lengkap dengan fasilitas makan dan minum serta fasilitas umum lainnya. Secara khusus hotel memiliki beberapa definisi menurut para ahli. Orang-orang yang sedang mengadakan perjalanan dengan maksud bisnis pejabat pemerintahan dan militer beserta keluarganya yang di tempatkan di negara lain tidak termasuk kategori ini, tetapi bila mereka mengadakan perjalanan ke negeri lain, maka dapat digolongkan wisatawan (Pendit, 1994). Hotel adalah fasilitas penyedia jasa penginapan/peristirahatan termasuk jasa terkait lainnya dengan dipungut bayaran, yang mencakup juga motel, losmen, pariwisata, wisma pariwisata, pesanggrahan, rumah penginapan dan sejenisnya, serta rumah kos dengan jumlah kamar lebih dari sepuluh (Siahaan, 2009)

Menurut Nurcholis (2007), pendapatan asli daerah adalah pendapatan yang diperoleh dari penerimaan pajak daerah, retribusi daerah, laba perusahaan daerah, dan lain-lain yang sah. Untuk mengetahui potensi sumber-sumber PAD menurut Thamrin (2001) ada hal-hal yang perlu diketahui kondisi awal suatu daerah besar kecilnya keinginan pemerintah daerah untuk menetapkan pungutan, kemampuan masyarakat untuk membayar segala pungutan-pungutan yang ditetapkan oleh pemerintah daerah peningkatan cakupandan intensifikasi penerimaan PAD kegiatan ini merupakan upaya memperluas cakupan penerimaan PAD.

\section{METODE PENELITIAN}

Jenis data yang digunakan dibagi menjadi dua yaitu: data kualitatif, adalah data yang dinyatakan dalam bentuk bukan bilangan, atau dengan kata lain data kualitatif adalah data yang disajikan dalam bentuk kata-kata yang mengandung makna (Noor, 2014:13). Data kualitatif dalam penelitian ini berupa gambaran umum Kota Langsa. Dan kuantitatif, adalah data yang dinyatakan delam bentuk angka-angka (Noor, 2014:14). Data kuantitatif pada penelitian ini berupa data jumlah wisatawan, jumlah pajak hotel, pajak restoran dan hiburan. Sumber data pada penelitian ini adalah data sekunder merupakan sumber data penelitian yang diperoleh peneliti dari Badan Pengelola Keuangan Daerah Kota Langsa, jurnal, buku, makalah dan brosur yang relevan dari berbagai sumber.

Metode ini menggunakan model Analisis Regresi Berganda (multiple linear regression method) bertujuan untuk memprediksi berapa besar kekuatan pengaruh lebih dari satu variabel independen terhadap variabel dependen, yaitu pengaruh jumlah kunjungan wisatawan, pajak hotel dan pajak restoran terhadap Pendapatan Asli Daerah. (Sugiyono, 2011). 


\section{HASIL DAN PEMBAHASAN}

Berdasarkan hasil pengolahan data yang dilakukan dengan bantuan SPSS dapat dibuat persamaan regresi linier berganda sebagai berikut:

Pengaruh jumlah wisatawan, pajak hotel, pajak restoran dan hiburan terhadap pendapatan asli daerah Kota Langsa dapat diketahui dari hasil analisis data dengan menggunakan persamaan regresi linier berganda.Perhitungan menggunakan program SPSS dengan hasil sebagai berikut.

Tabel 2. Persamaan Regresi Linier Berganda

\begin{tabular}{|c|c|c|c|c|c|c|}
\hline \multirow{2}{*}{\multicolumn{2}{|c|}{ Model }} & \multicolumn{2}{|c|}{$\begin{array}{l}\text { Unstandardized } \\
\text { Coefficients }\end{array}$} & $\begin{array}{l}\text { Standardized } \\
\text { Coefficients }\end{array}$ & \multirow[t]{2}{*}{$\mathrm{t}$} & \multirow[t]{2}{*}{ Sig. } \\
\hline & & $\mathrm{B}$ & $\begin{array}{l}\text { Std. } \\
\text { Error }\end{array}$ & Beta & & \\
\hline \multirow[t]{4}{*}{1} & (Constant) & ,969 & 1,095 & & ,885 & ,395 \\
\hline & Jumlah Wisatawan & ,288 & ,124 & ,300 & 2,328 & 040 \\
\hline & Pajak Hotel & ,579 & ,207 & ,382 & 2,797 & ,017 \\
\hline & $\begin{array}{c}\text { Pajak Restoran dan } \\
\text { Hiburan }\end{array}$ & ,378 &, 120 & ,364 & 3,152 & ,009 \\
\hline
\end{tabular}

$$
Y_{\log }=0,969+0,288 X_{1 \log }+0,579 X_{2 \log }+0,378 X_{3 \log }
$$

Jumlah wisatawan diperoleh $\mathrm{t}$ sig $<\alpha 5 \%(0,040>0,05)$ maka Ha diterima, dapat dinyatakan bahwa jumlah wisatawan berpengaruh signifikan terhadap pendapatan asli daerah Kota Langsa. Pajak hotel diperoleh $\mathrm{t} \operatorname{sig}<\alpha 5 \%(0,017<0,05)$ maka Ha diterima, dapat dinyatakan bahwa pajak hotel berpengaruh signifikan terhadap pendapatan asli daerah Kota Langsa. Pajak restoran dan hiburan diperoleh $\mathrm{t}$ sig $<\alpha 5 \%(0,009<0,05)$ maka Ha diterima, dapat dinyatakan bahwa pajak restoran dan hiburan berpengaruh signifikan terhadap pendapatan asli daerah Kota Langsa.

\begin{tabular}{|r|c|r|r|r|r|r|}
\hline \multicolumn{2}{|c|}{ Tabel 3 ANOVA } \\
\hline \multirow{2}{*}{ Model } & $\begin{array}{c}\text { Sum of } \\
\text { Squares }\end{array}$ & \multicolumn{1}{c|}{ df } & $\begin{array}{c}\text { Mean } \\
\text { Square }\end{array}$ & F & Sig. \\
\hline \multirow{2}{*}{1} & Regression & 3,384 & 3 & 1,128 & 72,265 & \multirow{2}{*}{, $000^{\mathrm{b}}$} \\
\cline { 2 - 8 } & Residual &, 172 & 11 &, 016 & & \\
\hline & Total & 3,556 & 14 & & & \\
\hline
\end{tabular}

Sumber: Data Primer diolah (2020)

Tabel 4 Koefisien Determinasi

\begin{tabular}{|c|r|r|r|r|}
\hline Model & R & $\begin{array}{c}\mathrm{R} \\
\text { Squar } \\
\text { e }\end{array}$ & $\begin{array}{c}\text { Adjusted R } \\
\text { Square }\end{array}$ & $\begin{array}{c}\text { Std. Error of the } \\
\text { Estimate }\end{array}$ \\
\hline 1 & $9^{9}$ &, 952 &, 939 &, 12494 \\
\hline
\end{tabular}

Sumber: Data Primer diolah (2020) 


\section{KESIMPULAN}

Berdasarkan hasil penelitian dapat dibuat kesimpulan sebagai berikut: hasil persamaan regresi linier berganda $Y_{\log }=0,969+0,288 X_{1 \log }+0,579 X_{2 \log }+0,378 X_{3 \log }$, hasil ini menunjukkan bahwa jumlah wisatawan, pajak hotel, pajak restoran dan hiburan memberikan pengaruh positif terhadap pendapatan asli daerah di Kota Langsa. Hasil uji t diketahui bahwa jumlah wisatawan dan pajak hotel berpengaruh tidak signifikan dan pajak restoran \& hiburan berpengaruh signifikan terhadap pendapatan asli daerah. Hasil uji $F$ diketahui jumlah wisatawan, pajak hotel, pajak restoran dan hiburan secara simultan berpengaruh signifikan terhadap pendapatan asli daerah Kota Langsa. Hasil uji koefisien determinasi $\left(\mathrm{R}^{2}\right)$ sebesar 95,2\% variabel jumlah wisatawan, pajak hotel, pajak restoran \& hiburan mempengaruhi pendapatan asli daerah Kota Langa, dan sebesar 4,8\% dipengaruhi oleh variabel lain yang tidak masuk dalam estimasi penelitian.

\section{DAFTAR PUSTAKA}

Arikunto, Suharsimi. (2006). Prosedur Penelitian Suatu Pendekatan Praktik. Yogyakarta: Andi.

Ghozali, Imam. (2016). Aplikasi Analisis multivariete dengan program IBM. Semarang: Badan Penerbit Undip

Hutahean, Akbar. (2015). Pengaruh Jumlah Kunjungan Wisatawan manca negara, pajak Hotel dan Tingkat Okupansi Hotel terhadap Pendapatan Asli Daerah Kabupaten Bintan 20132015.Jurnal Ekonomi. Vol 4.No.1.

Indriantoro, Nur dan bambang Supomo. (2011). Metodologi penelitian bisnisuntuk akuntansi dan manajemen edisi pertama. Yogyakarta : BPFE.Jakarta: PT Rineka Cipta

Mardiasmo. (2002) . Otonomi \& manajemen keuangan daerah. Yogyakarta: Andi.

Memah. (2013). Efektivitas dan kontribusi penerimaan pajak hotel dan restoran terhadap Pad Kota Manado. Jurnal EMBA, Vol. 1, No. 3.

Nasrul. (2003). Pengaruh Jumlah Kunjungan Wisata terhadap Pendapatan Asli Daerah.Jurnal Ekonomi. Vol 3.No.2.

Nawawi, Hadari. (2003). Manajemen sumber daya manusia untuk bisnis yangkompetitif. cetakan kedua. Yogyakarta: Gadjah Mada University Press.

Noor, Jualiansyah. (2014). Analisis Data Penelitian Ekonomi dan Manajemen. Jakarta: Grasindo.

Nurcholis. (2007). Ekonomi Pembangunan. Yogyakarta: BPFE.

Pendit, Nyoman S. (1994). Ilmu Pariwisata: Sebuah pengantar perdana. Jakarta : Rajawalipers.

Pertiwi. (2014). Pengaruh kunjungan wisatawan, retribusi obyek wisata dan phr terhadap PAD kabupaten Gianyar. E-Jurnal EP Unud, Vol.3, No. 3.

Siahaan, Marihot. (2009). Pajak daerah dan retribusi daerah. Edisi Revisi.

Sugiyono. (2011). Statistik Untuk Penelitian. Bandung: Alfabeta

Sutrisno, Denny. (2013). Pengaruh jumlah obyek wisata, jumlah hotel, dan pdrb terhadap retribusi pariwisata kabupaten/ kota di Jawa Tengah. EconomicsDevelopment Analysis Journal vol. 3, No. 4.

Thamrin. (2001). Pajak dan Retribusi Daerah. Jakarta: Ekonosia.

Undang-Undang No. 33 Tahun 2004 tentang PerimbanganKeuangan Antara Pemerintah Pusat dan Pemerintah Daerah

Undang-undang Nomor 10 Tahun 2009 Tentang Kepariwisataan

Undang-undang nomor 28 tahun 2009 tentang Pajak Daerah

Undang-undang Nomor 34 Tahun 2000 tentang Pajak dan Retribusi Daerah. 
Widodo, Wahyu Indro dan Guritno, Bambang. (2015). Pengaruh pajak Hotel, Pajak Restauran dan Pajak Hiburan terhadap Pendapatan Asli Daerah (PAD) di Kota Yogyakarta. Jurnal Visi. Vol 2. No. 2

Widyaningsihdan Budhi. (2014). Pengaruh jumlah kunjungan wisatawan terhadap penerimaan pajak hotel, pajak restoran dan pendapatan asli daerah. E-Jurnal EP Unud, Vol. 3, No. 4.

Wijaya dan Djayasastra. (2014). Pengaruh kunjungan wisatawan, jumlah tingkat hunian kamar hotel, dan jumlah kamar hotel terhadap pendpatan asli daerah (PAD) di kabupaten Badung, Gianyar, tabanan, dan Kota Denpasar tahun 2001-2010. E- Jurnal EP Unud, Vol. 3, No. 11. 